\title{
Putting Catholic religious education on the map
}

\author{
Colocando a educação religiosa católica no mapa
}

\author{
Adrian-Mario Gellel ${ }^{*}$
}

University of Malta, Msida, Malta

\begin{abstract}
This article presents the work published by a publishing company called Catholic Religious Education in Schools (BUCHANAN \& GELLEL, 2015). The volume brings together scholars from all six continents to reflect and discuss contextual, pedagogical and theoretical issues related to the teaching of the Catholic religion in a school context. In this sense, it is the first volume in the Catholic world to deal specifically with the theory and contextual issues of religious education as separate from Catechesis. While the former is understood that specifically occurs in formal education, the latter is understood that occur within the faith community environment. In an era of ecumenical and inter-religious and a society increasingly globalized and secularized, such a project may appear to be out of sync with reality. In addition to the work explains the construction of the project and its development proposed presentation of an international reality on the subject.
\end{abstract}

Keywords: Religious education. Denominational education. Search on Pedagogy.

AMG: Doctor of Theology, e-mail: adrian.gellel@um.edu.mt 
GELLEL, A.-M.

\section{Resumo}

Este artigo apresenta a obra publicada pela Editora denominada Educação Religiosa Católica nas Escolas (BUCHANAN \& GELLEL 2015). O volume reúne estudiosos de todos os seis continentes para refletir e discutir sobre contextual, as questões pedagógicas e teóricas relacionadas com o ensino da religião católica dentro de um contexto escolar. Neste sentido, é o primeiro volume dentro do mundo católico para lidar especificamente com a teoria e questões contextuais da educação religiosa como separada da Catequese. Enquanto o primeiro é entendido que ocorra especificamente no âmbito da educação formal, o último é entendido que ocorrem dentro do ambiente da comunidade fé. Em uma era de diálogo ecumênico e inter-religioso, bem de uma sociedade cada vez mais globalizado e secularizado, um projeto como este pode parecer estar fora de sincronia com a realidade. Além da obra explicita a construção do projeto e seu desenvolvimento que propôs apresentação de uma realidade internacional sobre o tema.

Palavras-chave: Educação religiosa. Educação confessional. Pesquisa em Pedagogia.

\section{Introdução}

A few months ago, Springer published an edited collection on Catholic Religious Education in schools (BUCHANAN \& GELLEL, 2015). The volume brings together scholars from all the six continents to reflect and discuss on contextual, pedagogical and theoretical issues related to the teaching of Catholic Religion within a school context. In this sense, it is the first volume within the Catholic world to specifically deal with the theory and contextual issues of Religious Education as separate from Catechesis. Whilst the former is understood to specifically occur in the context of formal education, the latter is understood to occur within the faith community setting. In an age of ecumenical and inter-religious dialogue, as well of an increasingly globalised and secularised society, such a project may appear to be out of sync with reality.

When we embarked on this project some four years ago, we were moved by the belief that this endeavour was not only worthwhile but that it was also a means to negotiate and assert an identity within the Catholic 
Church, as well as within the academic community of educationalists, theologians and Religious Education scholars. Indeed, this process is needed to enhance, and in some cases to begin, dialogue with colleagues, members of the believing community and society at large. It is expected that this publication will contribute towards the development of a community of practice among catholic scholars working in the field. In the long term, it can contribute not only to enhance and strengthen the mission of the Catholic Community, but it can also contribute to strengthen the process of dialogue with the wider community of scholars and practitioners working in the field of Religious Education. Above all, we believe that by strengthening the identity of Catholic Religious Education and by clarifying related issues we will be contributing towards a means of being more authentic to the message received through theological and pedagogical reflection while strengthening the educational mission of the subject. Without being too presumptuous, this project is mainly intended to put Catholic Religious Education on the map. During these past decades, the changes in society, in the educational sector as well as in the universal Church, have paved the way for the development of Catholic Religious Education as a discipline on its own, separate from other theological and pedagogical subjects. Yet, it is my contention that Catholic Religious Education as an academic discipline is still hazy. It is not uncommon to find academics, or even members of the Catholic hierarchy, who confuse Catholic Religious Education either with the academic discipline of Catholic Education, that is Catholic schooling, or with Catechesis, that is the faith formation of those who have made a conscious decision to become disciples of Christ. Truth be told, at times this fuzziness originates from the inability to comprehend the areas of study of each of the above mentioned disciplines. However, many a time, this fuzziness is also due to ideological and theological pre-concepts.

\section{Seeds of a new discipline}

The teaching of Sacred Scripture, Doctrine and/or Morals have for long featured in the school curricula of Church, but also of State, schools. For instance, as from the late $17^{\text {th }}$ century, but definitely by the 
end of the 18th century, the Austrian empire, which comprised most of central Europe, had a vast network of parish schools. These schools were far from what today would be considered proper schools, (MELTON, 1986) but they did serve a basic function of social reproduction and of instilling a sense of identity as well as a sense of belonging. Society was predominantly oral, and the literacy revolution was still yet to come.

Nonetheless, the physiognomy of the subject was not only determined (and maybe limited) by a non-literate society, where it was not uncommon to find clergymen or rulers who were particularly suspicious of literacy (MELTON, 1986). There were other factors that influenced the nature and role of the teaching of religion during this period. Scholastic disciplines are after all social artefacts "conceived of and made for deliberate human purposes" (GOODSON, 1995, p. 199). Thus, it is not surprising that there are many factors that influence the very definition of the discipline as well as the content that it delivers. In this regard there are many historical examples of how ideology and politics influenced the teaching of religion. For instance, within a nineteenth century Scottish Calvinistic society, Hamilton, as cited by Goodson (1995), reports how the will to restrain class mobility led to the use of a theology of predestination in the formation of a curriculum. In this circumstance, the curriculum was designed in such a way as to provide the lower classes with only religious knowledge and an education of the virtues. Likewise, within Catholic circles, religious instruction in schools was seen as a means to counter the teachings of the reformation and to maintain a homogenous community.

For most of these past five hundred years, Catechesis and Religious Education were prevalently the same. Thus, it is of no surprise that many cannot understand the two as being distinct. Up till a few decades ago, the subject taught in schools followed the same logic in the need for, as well as in the formulation of the Catechism. As a tool, the Catechism is mainly a product of the modern period which was characterised by the invention of the printing press, the split between Catholicism and Protestant denominations as well as the rise of European nationstates. Even though there are examples of some form of Catechisms or Catechetical handbooks during the medieval period, such as for instance 
Honorius Augustodunensis' Elucidarium of the late eleventh century Britain, Antonio Pierozzi's Libretto della dottrina of 1473 in Italy or John Gerson's Opus tripartitum in early fifteenth century France, the need, as well as the definitive structure and pedagogy of the Catechism did not become clear until the sixteenth century (BRAIDO, 1991; GERMAIN, 1987, SLOYAN, 1983).

Up till the Renaissance, only ten percent of the European population knew how to read and write so, consequently, Catechesis was mainly done either through socialisation, liturgy and devotional piety or through preaching (GROPPO, 1987; TURNER, 2000). The structure and pedagogy of Catechesis was determined by a perceived Christian homogeneity, but most of all by a predominant oral culture. A growing concern with religious ignorance in the late fifteenth century together with the advent of Protestant and Catholic reformations, paved the way for the introduction of the Catechism. Indeed the Catechism responded to specific requirements of the period, that is, the instruction of the believers in the basics of faith so as to construct their Christian identities, combat heresies spread by the opposing Churches, and thereby ascertain the salvation of the catechised. In this regard it is good to mention Luther's Small and Large Catechisms together with Calvin's Catechism in the Protestant world, and the Roman Catechism, Bellarmino's as well as Canisius Catechisms in the Catholic world. All five catechisms devised their own structure. Even though the Catechisms were inspired by a Socratic method, the published questions and answers often led to parrot-like rote learning and, consequently to a reductionist understanding of the faith. As Marthaler (1978) rightly notes, the printing of the Catechism imposed a standardisation that was previously unknown. With printing, doctrine was crystallised and dialogue became difficult. While in the previous centuries, copyists did not mind to adapt the text according to the recipient of the manuscript, the published text compelled the catechist to follow the printed question and to expect the standard answer.

The publishing of the Catechisms led to the need to organise and structure the contents of faith in a logical sequence by using smaller sections. This inevitably meant that the contents of the faith had a perceived beginning and an end, creating the false impression that 
the Catechism was exhaustive in matters that concerned the faith. Furthermore, the printed question and answer method limited the Socratic method that had originally inspired it, leading to a fragmentation of the content and a disjoining of the whole. Importance was given to finding ways and means of including all aspects of the faith in one book. Yet, the Catechism could never reflect the richness and depth of the lived faith passed on and delved into by subsequent generations of believers in different contexts. Indeed, this was different from how the faith was transmitted in the previous centuries.

It should however be noted that it was precisely for this reason that in a number of contexts the Catechism was supplemented by other methods. For instance, throughout the seventeenth century, the teaching of religion in the Austrian empire was taught in and through different ways, including liturgical music, theatre and eventually the reading of the Bible in vernacular language, which was considered as an important means of defending orthodoxy (MELTON, 1986). It is evident that these 'scholastic subject/s' were more intended for those who had already been socialised into the Catholic faith and who were sustained by the pious and para-liturgical practices of a wider Catholic society. Literacy was not always seen as a priority for scholastic activities.

\section{Towards the emergence of Religious Education}

From the above escursus, it isn't difficult to deduce that the difference between Catechesis and religious instruction was more that just blurred. The composition of society, as well as the nature of the educational entreprise shaped the aims, method and content of Religious Education. However, between the second half of the nineteenth century and the first decades of the twentieth century, the scenario was slowly set to change. The advent of the industrial revolution, which led to a more urbanised socety, brought with it new social realities that included the exploitation of minors, social unrest and the dechristianisation of society. This coincided with the widespread practice of compulsory schooling in most European countries. Yet, the introduction of compulsory education confronted teachers with a wide spectrum of abilities and aptitudes. 
These changes in society and the novel widespread introduction of public education occured at a time when the philosophies of existentialism and phenomenology, as well as the discipline of psychology, all of which highlighted the importance of experience, were being developed. Philosophy and the new emerging field of psychology were contributing to a new understanding of pedagogy and consequently a new conceptualisation of scholastic disciplines. It was through these philosophies that in the late nineteenth century new ideas related to the pedagogy of Catechesis and religious instruction in schools were germinating. During the same period, philosophers in Britain and in Germany became interested in psychology since they saw it as a means to start discourse on a coherent theory of knowledge and logic that in turn had an impact on education (MORGAN, 1997).

The above mentioned transformations in academia, education and society put the child and the adolescent in the limelight. Indeed, within the Catholic Church, it is during this period that we find more attention to the pastoral requirements of the child. At this point, it suffices to mention the pastoral and pedagogical work of St John Bosco at the end of the nineteenth century while, in the secular realm, one should note the Belgian concern for the promotion of children's welfare at the beginning of the twentieth century (MARSHALL, 1999).

By the late nineteenth century, the growing dissatisfactions with the institutional Church and the rise of philosophies that were antagonistic to Christianity led to new scenarios. In France, the 1882 legislation on education removed the teaching of religion from public schools. This led to an increase in the participation of the laity, especially females, in Catechesis but also in the teaching of religion in Church owned schools. It is within the latter context that experimentation with methods and new ideas took place (COKE, 1983, 1985). The recognition that a considerable number of students pertained to families that were indifferent to religion and no longer practiced Christianity meant that the methods of the past were no longer efficacious. The family religious socialisation unit was missing and therefore children went to Catechesis/Religious Education without any prior knowledge and without any support for a committed Christian life. Indeed it was noted that as soon as they received their 
first Holy Communion, most of them would no longer participate in the liturgy. In this scenario, there was an increasing understanding that the point of departure could no longer be faith in Christ and therefore what was being proposed could no longer be called Catechesis (COKE, 1983). In the German world, catechists were responding to the challenges of learning through the Herbart's philosophy. Unsatisfied with the traditional question and answer approach, Tuiskon Ziller adapted Herbart's approach to Catechesis by adopting three simple steps, later identified as the Munich method. Lessons were structured through presentation, explanation and application. According to Marthaler (1978), even though the Munich method, as it was later identified, was criticised, it left us the legacy of lesson development through the use of lesson plans. From these two European contexts we note a more explicit interaction with the emerging modern educational sciences. However, it should be noted that from its very inception, given the centrality of its teaching ministry, the Christian community always interacted and reflected with ideas in education. For instance, Slavin (1936) pointed out how through the past millennia, Christian authors including Clement of Alexandria, Augustine, Jerome, Ambrose, Abelard, Bonaventure, Albert the Great, Aquinas, Scotus, Occam and Ignatius of Loyola interacted with the ideas of their times to reflect on educational issues. Nevertheless, at the end of the nineteenth century, it is the interaction in and within the school, the new social scenario as well as this new audience that little by little brought in the need to introduce the educational discourse as well as the need of a more conscious engagement with the emerging educational sciences.

Meanwhile, in the Anglo-Saxon protestant world, a clearer understanding of the meaning of Religious Education was emerging in the United States and in England with the latter context providing a clearer direction for the establishment of Religious Education in schools as separate from Catechesis. The founding of the Religious Education Association in the US in 1903 was spurred, among others, by a desire to respond and integrate the knowledge that was developing in the area of the educational sciences, especially psychology. From the first convention it was soon evident that the protestant (white) religious and academic communities were taking on the responsibility to develop a discipline 
that would make religion as a central enterprise for education at every level of life. William Harper, who is credited to be the founding father of the association, wanted to bring together the efforts in religious and moral education. He proposed that the association should bring biblical literacy to the wider populations through the formal and non-formal sectors of education (MOORE, 2003). The interdisciplinary character of the discipline was soon evident. The convention was addressed by John Dewey, the leading philosopher, psychologist and educationalist at the time, as well as other psychologists and sociologists. Within three years from the first convention, major American universities initiated academic programmes and departments in Religious Education within both Theology and Education Schools or Faculties.

Within Catholic circles, modest inroads were also being made. During the first part of the twentieth century, there were three major issues that spurred development in catechesis/religious instruction, namely the irreligious character of public schools, the religious indifference of parents and the advancements in the educational sciences. This led a multitude of individuals and religious congregations all across Europe, as well as in the Americas, to develop and experiment with different methods that give more attention to the needs of the child and that follow pedagogical insights. Consequently, it is not surprising that the Catechetical Congress of Vienna and that of Munich, organised in 1912 and 1928 respectively, emphasised the methods of how to teach the catechism rather than the content (BANDAS, 1957). Yet, after the Second World War, the interest of the Catechetical Movement shifted from method to content.

Concurrent with these changes, the Church was experiencing a renewed interest in the writings of the Fathers of the Church and in the Liturgy, which in turn gave a new impetus to the rise of the Catechetical Movement. The work of Josef Jungmann, an Austrian Jesuit and a professor of pastoral theology at Innsbruck is interesting. His research in the practice of the early church and in the liturgy led him to understand the connection between liturgy and Catechesis. At Innsbruck he taught Liturgy, Catechetics and Pedagogy. He emphasised the need to approach the message through the annunciation of the Kerygma which centred on the person of the risen Christ (JUNGMANN, 1959). Through his/her 
encounter with the person of Christ, the student should experience the joy of the message.

His thoughts had an impact not only on Catechesis but especially on Religious Education (see for instance BUCHANAN, 2005). It is at this point that a clear rupture between Catechesis and Religious Education in schools becomes evident. The Kerygmatic approach relied heavily on the biblical message. Within ten years from its inception, the Kerygmatic approach was encountering serious difficulties in French and German school contexts. On the one hand, most of the pupils were not socialised as Christians and therefore were not familiar with Christian stories, while on the other hand, the social climate of the sixties meant that Religious Education had to justify its relevance within the context of public education. Religious Education had to justify its presence on the basis of cultural and rational arguments.

This led to new approaches in Religious Education. During the late sixties and the early seventies Religious Education in schools started to focus on the existential experience of pupils. The Second Vatican Council insisted that God was the source of revelation and that the present-day life and revelations were not separate from each other. This strengthened the need for an approach that was more life-centred. A variety of pedagogical approaches that gave more importance to the relationship between the Christian message and the life, as well as the experiences, of the students started to crop up in different parts of the Catholic world. Suffice to mention Thomas Groome with his conception of Christian Shared Praxis and whose influence was not only limited to the United States, as also the Life-centred Approach as conceptualised by Amalorpavadass, an Indian Jesuit priest who influenced Religious Education in Australia, as well as the Anthropological Approach and Correlation methods that were inspired by the protestant theologian Paul Tillich and the Catechetical Institute of the Salesian University in Rome (BUCHANAN, 2005, GEVAERT, 1984).

The vision of the Second Vatican Council continued to spur this distinction between the two disciplines. The openness to the world, expressed in Gaudium et Spes, the deeper understanding of the reality of God's Revelation in Dei Verbum and the renewed understanding of what it means to be Church in Lumen Gentium, became the foundation pillars 
of Religious Education in schools as a discipline in its own right that is autonomous but at the same time cherishing close, but not exclusive, ties with Catechesis. The decade following the Council was the most intense and prolific with regards to the themes of evangelisation and Catechesis. Yet, in the official Church documents there was still nothing that acknowledged the need for a separation between Catechesis and Religious Education.

\section{Birth Pangs}

The birth of Religious Education as a distinct discipline has been complex. Although in the academic world there were calls for a distinction from Catechesis (see for instance Istituto di Catechetica dell' Università Salesiana 1971, Moran, 1974, Rossiter, 1982, Scott, 1980), it was only in 1981 that the Universal Church little by little started to acknowledge the peculiarity of Religious Education in comparison to Catechesis. Just two years before, Catechesi Tradendea, an Apostolic Exhortation that was the result of a Synod of Bishops on Catechesis and which was edited by three different Popes, still considered religious instruction to be an integral part of Catechesis (Pope John Paul II, 1979).

During these past three decades, the processes of secularisation and post-secularisation, as well as the complex political scenarios, including the post-9/11 events, have greatly influenced the debates surrounding the discipline and its developments. Within Catholic circles, the pedagogy and the contents have also been influenced by the particular context of the Church and educational developments. For the purpose of this section, I shall only make reference to the Universal Church's official recognition of Religious Education as distinct from Catechesis, since, thirty-five years after this recognition, there are still many dioceses and academics who are uncertain about the meaning and application of such acknowledgment.

The first conceptual notions of the distinction and complementarity between Religious Education and Catechesis were put forward by the late Pope John Paul II (1981) when he was speaking to the priests of his own diocese on the religious formation of the young. It is important to note that this affirmation was made by the Pope when he was referring to the reality of public schools. The Pope acknowledged that any discourse on 
religion is marked by the pedagogical context in which it is conducted. It is for this reason that Religious Education should be marked by the aims and structure of the school. Such a Religious Education carries the dual role of fulfilling the right and obligation of every human person while at the same time it is a service that society renders to catholic students. John Paul II argued that those responsible for Religious Education in public schools must make sure that the subject coordinates its contents and pedagogy with the other subjects in order to offer and assure an integral human formation.

Yet, besides acknowleding the distinction between Catechesis and Religious Education, the Pope also insisted on the intimate relationship between the two disciplines since they both have the same audience and both make reference to the same content. However, according to the Pope, Religious Education may be considered to be both a pre-catechetical activity as well as an opportunity for one to delve further into specific themes of Catechesis.

However, this elucidation took quite some time before finding a definite place in the official Church's position on the subject (CONGREGATION FOR THE CLERGY, 1997, CONGREGATION FOR CATHOLIC EDUCATION, 1988, 2009). Then again, notwithstanding the elucidations of the Circular letter on Religious Education, some feel that the repeated indications on the distinction yet complementarity between Religious Education and Catechesis still lacks clarity (for instance FRANCHI, 2013).

One of the main issues that hinders clarity in this area lies in the fact that Catholic Religious Education is taught in both Catholic Church schools and public State schools. Without diminishing the importance of the fact that in both types of schools the students may not necessarily be practicing Catholics or, for what it matters, even nominally Christian, the main issue lies with the aims of the two different types of schools. There is no quibbling about the fact that the Church understands its schools to be a means of evangelizing and that, at least at a notional level, Religious Education is understood to be a central curricular subject which should permeate all other disciplines as well as the extra and hidden curricula of the school (JOHN PAUL II, 1992). The reality of having Catholic Religious Education given in both state and church schools is not present 
in most English-speaking countries. Indeed, in most of these countries, Catholic Religious Education is only provided in Catholic Church Schools. Consequently, it is understandable that scholars, as well as members of the institutional Church, in these countries find it difficult to understand in real terms the distinction that is required from Religious Education as separate from Catholic Education and from Catechesis.

The elucidation on what the Holy See understands by the phrase "distinction and complementarity" between Religious Education and Catechesis was made by the Popes when they specifically spoke of Catholic Religious Education in the context of State Schools. In his letter to the President of the Italian Episcopal Conference on the recent amendments to the Agreement between the Church and the Italian Republic on Catholic Religious Education in State Schools, Pope John Paul II (1985) insisted that Religious Education is an integral part of the holistic education of the human person. The Pope argued that Catholic Religious Education should contribute to the constant search for meaning and to the formation of a secular conscience that is able to make good choices as well as, within an Italian context, it should help students to understand their own culture and history. The same line of argument was made a few years later when the Pope was addressing members of a symposium organised by the European Conferences of Bishops. Besides forwarding the same arguments proposed six years earlier, the Pope insisted that Catholic Religious Education should promote the knowledge and the encounter of students with the Christian faith according to the aims and methods of the school, and consequently, within the context of a state school, Religious Education should be understood as a subject that deals with culture (POPE JOHN PAUL II 1991). John Paul II believed that it is through dialogue with believing and nonbelieving students that the discipline and its teachers may contribute to the search for truth. On the other hand, the confessional nature of the subject ascertains the students' right to know Christ and his message. These thoughts are further clarified by Pope Benedict XVI (2009, p. 1), in his address to Italian Catholic Religious Educators: 
The religious dimension is in fact intrinsic to culture. It contributes to the overall formation of the person and makes it possible to transform knowledge into wisdom of life[...]

[...]Thanks to the teaching of the Catholic religion, school and society are enriched with true laboratories of culture and humanity in which, by deciphering the significant contribution of Christianity, the person is equipped to discover goodness and to grow in responsibility, to seek comparisons and to refine his or her critical sense, to draw from the gifts of the past to understand the present better and to be able to plan wisely for the future.

The concept of "complementarity and distinction" becomes clearer when one takes into consideration that the Popes were specifically speaking about Religious Education that occurs in state schools. Indeed, given that this is a secular context and that the aims of this education are totally dependent on the State, the difference between Religious Education and Catechesis becomes evident. However, it should also be noted that the difference between the aims of the Catholic school and those of a State school as well as between the two student populations are not so great as to warrant a difference between the Catholic Religious Education that occurs in the two scholastic settings. Even though the Catholic school aims to promote the human person in his/ her totality in the light of the salvific message of Christ, it not only does so with the same instruments, methods and structures available in States schools but it also commits itself to prepare citizens who meet the required standards set by the State for all formal education. Furthermore, it is difficult to argue, even though there are some who do so, that a Church school can be considered to be a faith community. This is mainly due to the formal setting and the power structure that are inherent to any school as well as the diverse population that attends the school. Thus, while acknowledging that the aims of a Catholic school facilitate faith formation, these do not necessarily pertain to the initiatory or mystagogical Catechesis precisely because the other three dimensions of pastoral ministry, namely koinonia, diakonia and leiturgia (Cf. FLORISTAN, 1983), may only be weakly present in a school setting.

Consequently, while the State school provides the clearest setting to understand the distinction between Catechesis and Religious Education, the Church school setting presents the clearest scenario where Catechesis and Religious Education are complementary. Nonetheless, it can be 
argued that in both contexts, and in different degrees, the two conditions set by the Popes and by the Magisterium are possible and desirable.

\section{The Publication of the Global Perspectives on CRE as a Journey}

As shown in the preceding sections, it is quite clear that the lack of clarity of terms and language in the discourse about Catholic Religious Education has made it difficult for the discipline to develop its proper vocation and status. Moreover, the problem is exacerbated by the diverse contextual situations of local churches across the world. Thus, the idea, of publishing a book that brings together the research, challenges and experiences of catholic academics in the field of Religious Education which had been brewing in my mind for more than a decade. My doctoral studies had pointed to the richness that exists in the Catholic world and yet it seems that, especially in the Anglophone world, this richness was not well known or given adequate attention. It seemed to me that, when compared to their Protestant colleagues, Catholics working in Religious Education were less networked and tended to keep a low profile.

In my encounters with colleagues, especially during conferences, I was always struck by how Catholic scholars are easily identifiable through their particular stance in research. Yet I felt that there were very few opportunities for Catholics working in the field of Religious Education to come together to share and discuss. There are only a handful of journals, some of which faculty based, that deal with or include Religious Education within their scope. Of course, to state that up till now there has not been any publication that dealt with Catholic Religious Education in schools would be incorrect. Indeed there have been, and there still are, catholic scholars working in the field who have sought to bring forward their perspectives or theoretical frameworks. Yet, I felt that not enough was being done to highlight the richness and the universality of the subject and, more specifically, to explore contemporary perspectives on Catholic Religious Education throughout the world as an academic discipline with its own pedagogy and methods. Indeed, there are a number of publications in the area that are either limited to one country or one region or that deal with Catholic Education, Catholic Religious Education 
and Catechesis within the same volume with at least two of the terms being used interchangeably.

In the immediate years after my doctorate, the need for a volume that explores contemporary perspectives on Catholic Religious Education throughout the world as an academic discipline with its own pedagogy and methods was palpable. This was evident in the consensus that I would gather every time I shared the idea with European colleagues. In this regard, my encounter with Michael Buchanan from the Australian Catholic University was providential. He spurred me to start working on the project and together we began working on how to translate this idea into a concrete proposal. His experience as the then editor of the Religious Education Journal of Australia contributed to widen the initial list of contacts and to give a concrete direction to the project.

In order to ensure a high level of contemporary and forwardthinking scholarship in the area, Michael and I made sure that contributing authors met five basic criteria, namely that they were (i) Catholic academics, (ii) with expertise and scholarship in the field of Catholic Religious Education, (iii) who held a $\mathrm{PhD}$ (or equivalent), (iv) who were affiliated with a University (or Higher Education Institution) and (v) who were able to publish in English.

The contributing authors, while experts in Religious Education, were also chosen because they had the potential to bring fresh perspectives on Catholic Religious Education that is relevant to a contemporary world. Furthermore, we wanted to make sure that the edited collection builds upon the contributions offered by scholars over the past five decades rather than recreate what had already been achieved.

The edited collection is based on the premise that Catholic Religious Education in schools is accessible to many students in many countries throughout the world and that there is a richness of international research and expertise pertaining to Catholic Religious Education that deserves to be shared internationally. This richness is not only present in Catholic Schools but, in many countries, even in State schools. Through the book, we wanted to provide an opportunity for academics to share their research and expertise, to discuss challenges and to explore creative ways to advance teaching and learning in Catholic Religious Education in 
schools everywhere. We believed that one effective way of achieving this was to propose an edited book for publication with contributions from scholars from all the global regions: Africa, Asia, Australia, Europe, North and South America. This will hopefully give impetus to the setting up of a network of scholars who can clarify and sustain the identity of the subject within and outside Catholic circles.

Thus, the desire to facilitate this coming together was not spurred by sectarian motivations. This would have gone against what we believe it means to be truly Catholic, that is to embrace universality. The latter understanding should influence the way we understand and approach knowledge as well as the way we relate with the world. Consequently, a second motivation for the publication of this collection was the will to respond to Pope Paul VI's (1975) invitation to be truly faithful to both the message and the students with whom we are to share it. This implies that we need to continue in our endeavour and commitment to reflect through the educational sciences and theology.

We felt the need for scholars, church leaders and practitioners to share their own experiences, reflections, research, difficulties and hopes within a community that speaks the same language. This is first needed because there is an urgent need for Catholic scholars to become more aware of the different realities and expectations in various contexts. The presence of the church in different parts of the globe brings about a richness of practice, research and expertise that is in urgent need to be discovered and disseminated.

At the initial stages, one of the main problems that we encountered was the predominance of European, followed by Australian and Canadian scholars. Initially it was extremely hard to get in touch with academics residing in the Asian, African and South American regions. Whilst the issue with the latter was mainly due to a language barrier, in the former two cases we were also constrained by limited information and by an academic tradition that is still developing. Already at this stage, we could sense how much context influences and shapes communication and ideas. A list of scholars that included at least two academics from each region was made possible with the help of the contributors to the book. The need for networking is evident. 
The volume is divided in two major parts. The first section, which comprises six papers, deals with the theoretical foundation of the subject, while the second section, which deals with contextual issues, comprises seventeen papers. Whilst going through all the papers, not just those in the second section, one notes the richness and theoretical insight that the context provides. Indeed one immediately notes and becomes aware how being part of a minority community, the reality of secularization, having Religious Education solely in church schools, living in countries that are or where traditionally Catholic, living deeply religious and/or multi-faith societies shapes the outlook of the authors. Yet at the same time one also notes that there is a corpus of literature that normally includes the local and universal magisterium of the Church that unites the underlying thought of the authors. Prof. Gloria Durka (2015), has rightly compared the reading through this volume as a looking through a kaleidoscope. It is the same Catholic Religious Education viewed through the lens of different context. On the one hand there is an invitation to retrieve meaning and to clarify the nature and mission of Catholic Religious Education in schools, while on the other hand most of the chapters that are a witness to a commitment of innovation and to make the teaching of Catholic religion meet the requirements of it audience. Indeed, this is an evident will to identify and face the challenges posed by the context, new pedagogical approaches and by the learners.

\section{Conclusion}

Catholic Religious Education is an essential element of the teaching ministry of the Church. However, unless the language within this ministry, and especially with regards to the area of the teaching of religion in schools, is clarified the mission of the Church will be hampered. It is a pity that in an age of globalisation where communication and the sharing of information are so easy, the believing members of the Catholic community, at least where Religious Education is concerned, are still far from living the ideal of Catholicity (universality). Without diminishing the crucial role and impact of the context, there is a peculiar pedagogy, an educational philosophy and theological framework that awaits to be 
retrieved, shared and reflected upon. This may only be done through a specialised network that is only concerned with the teaching of Catholic Religion in school.

\section{References}

BANDAS, G. R. Contents and methods of catechization. Minnesota: The Confraternity of Christian Doctrine of the Archdiocese of St Paul, 1957.

BUCHANAN, M. T. Pedagogical drift: The evolution of new approaches and paradigms in religious education. Religious Education, v. 100, n. 1, p. 20-37, 2005.

BUCHANAN, M. T.; GELLEL, A. M. (Eds). Global Perspectives on Catholic Religious Education in Schools. Switzerland: Springer, 2015.

BRAIDO, P. Lineamenti di storia della catechesi e dei catechism. Dal «tempo delle riforme» all'eta degli imperialismi (1450-1870), Leimann (Torino): Elle Di Ci, 1991.

COKE, M. P. The early catechetical renewal in France and its influence in the teaching of Religion. (Unpublished doctoral Thesis) Durham: Durham University, 1985. Available from: <http://etheses.dur.ac.uk/7240/>. Access in: 04 may. 2016.

COKE, M. Catechetical renewal and its implications for RE. British Journal of Educational Studies, v. 31, n. 1, 29-40, 1983.

CONGREGATION FOR THE CLERGY. General Directory for Catechesis, 1997. Available from: <http://www.vatican.va/roman_curia/congregations/cclergy/documents/ rc_con_ccatheduc_doc_17041998_directory-for-catechesis_en.html〉.

CONGREGATION OF CATHOLIC EDUCATION. Circular Letter to the Presidents' of Bishop's Conferences on Religious Education in Schools, 2009. Available from: <http://www.vatican.va/roman_curia/congregations/ccatheduc/documents/ rc_con_ccatheduc_doc_20090505_circ-insegn-relig_en.html>.

CONGREGATION OF CATHOLIC EDUCATION. The Religious Dimension of Education in a Catholic School. Guidelines for Reflection and Renewal, 1988. Available from: <http://www.vatican.va/roman_curia/congregations/ccatheduc/ documents/rc_con_ccatheduc_doc_19880407_catholic-school_en.html >. 
GELLEL, A.-M.

DURKA, G. Preface. M. T. Buchanan, A. M \& Gellel. (Eds). Global Perspectives on Catholic Religious Education in Schools. Switzerland: Springer, 2015.

FLORISTAN, C. Acción Pastoral. C. Floristan \& J. J. Tamayo (eds.). Conceptos fundamentales de pastoral. Madrid: Cristiandad, 1983.

GERMAIN, E. Catechismo (istituzione). In: GEVAERT, J. (ed.), Dizionario di Catechetica. Leimann, Torino: Elle Di Ci. 118-119, 1987.

GEVAERT, J. La dimensione esperienziale della catechesi. Leumann (Torino): Elle Di Ci, 1984.

GOODSON, I. F. (ed.). The making of the Curriculum: Collected Essays. Washington D.C: Falmer Press, 1995.

GROPPO, G. Medioevo (Catechesi del). In: GEVAERT, J. (ed.), Dizionario di Catechetica. Leimann (Torino): Elle Di Ci. 1987. p. 411-415.

ISTITUTO DI CATECHETICA DELL' UNIVERSITÀ SALESIANA (ed.). Scuola e religione. 1. Una ricerca internazionale. Situazione, problemi, prospettive. Leumann (Torino): Elle Di Ci, 1971.

JUNGMANN, J. A. Handing on the Faith. A Manual of Catechetics. West Germany: Herder, 1959.

MARSHALL, D. The construction of children as object of international relations: the Declaration of Children's Rights and the Child Welfare Committee of League of Nation, 1900-1924. The International Journal of Children's Rights, v. 7, n. 2, p. 103-148, 1999.

MARTHALER, B. L. The modern catechetical movement in Roman Catholicism: Issues and personalities. Religious Education, v. 72, n. S1, p. 77-91, 1978.

MELTON, J. V. H. From Image to Word: Cultural Reform and the Rise of Literate Culture in Eighteenth-Century Austria. The Journal of Modern History, p. 95-124, 1986.

MOORE, A. J. One Hundred Years of the Religious Education Association. Religious Education, v. 98, n. 4, p. 426-436, 2003.

MORAN, G. Two languages of religious education. The Living Light, v. 14, p. 40-50, 1974.

MORGAN, H. Cognitive styles and classroom learning, Connecticut: Praeger, 1997. 
POPE BENEDICT XVI. Address of His Holiness Pope Benedict XVI to the Catholic Religion Teachers, 2009. Available from: <http://w2.vatican.va/content/benedict-xvi/en/speeches/2009/april/documents/hf_ben-xvi_spe_20090425_insegnanti-religione.html>.

POPE JOHN PAUL II. Discorso di Giovanni Paolo II ai partecipanti al simposio del Conisglio delle Conferenze Episcopali d'Europa sull insegnamento della Religione Cattolica bella scuola pubblica, 1991. Available from: <https://w2.vatican.va/content/john-paul-ii/it/speeches/1991/april/documents/hf_jp-ii_spe_19910415_ insegnamento-religione.html>.

POPE JOHN PAUL II. Lettera del Santo Padre Giovanni Paolo II al Cardinale Ugo Poletti, Presidente della Conferenza Episcopale Italiana, 1985. Available from: <https://w2.vatican.va/content/john-paul-ii/it/letters/1985/documents/hf_jp-ii_ let_19851231_card-poletti.html>.

POPE JOHN PAUL II. Discorso del Santo Padre Giovanni Paolo II ai sacerdoti della Diocesi di Roma, 1981. Available from: <http://www.vatican.va/holy_father/john_paul_ii/speeches/1981/march/documents/ hf_jp-ii_spe_19810305_sacerdoti-diocesi-roma_it.html>.

POPE JOHN PAUL II. Apostolic Exhortation Catechesi Tradendae on Catechesis in our time, 1979. Available from: <http://www.vatican.va/holy_father/john_paul_ii/apost_exhortations/documents/ hf_jp-ii_exh_16101979_catechesi-tradendae_en.html>.

POPE PAUL VI. Apostolic Exhortation Evangelii Nuntiandi, 1975. Available from: <http://w2.vatican.va/content/paul-vi/en/apost_exhortations/documents/hf_p-vi_exh_19751208_evangelii-nuntiandi.html>.

ROSSITER, G. M. The need for a "creative divorce" between catechesis and religious education in Catholic schools. Religious Education, v. 77, n. 1, p. 21-40, 1982.

SCOTT, K. Communicative Competence and Religious Education. Lumen Vitae. International Review of Religious Education, v. 35, n. 1, 75-96, 1980.

SLAVIN, R. J. The philosophical basis for individual difference according to saint Thomas Aquinas, Washington D.C.: Catholic University of America, 1936. 
GELLEL, A.-M.

SLOYAN, G. S. Religious Education: From Early Christianity to Medieval Times. M. Warren (ed.), Source Book for modern Catechetics. v. 1. Minnesota: St Mary's Press, p. 110-139, 1983.

TURNER, P. Ages of Initiation. The first two Christian millennia. Collegeville, Minnesota: The Liturgical Press, 2000.

Received: 06/16/2016

Recebido: 16/06/2016

Approved: 07/29/2016 Aprovado: 29/07/2016 